Journal of Reproduction and Development, Vol. 39, No. 4, 1993

\title{
Superovulation in Beef Cows and Heifers with a Single Injection of FSH dissolved in Polyvinylpyrrolidone
}

\author{
Masao YAMAMOTO, Tatsuyuki SUZUKI, \\ Masato OOE and Mitsuhiro TAKAGI \\ United Graduate School of Veterinary Science, \\ Yamaguchi University, Yamaguchi 753, Japan
}

\begin{abstract}
This study was designed to establish the efficacy of $30 \%$ polyvinylpyrrolidone solution (PVP; molecular weight 40,000 ) as a solvent for follicle stimulating hormone (FSH) as a single intramuscular (i.m.) injection for superovulating beef cattle and to compare its efficacy in inducing superovulation with descending doses of FSH dissolved in saline. In experiment 1, 16 Japanese Black cows were randomly alloted to 2 treatment groups. Each of the 8 cows in the PVP group or saline group were given a single i.m. injection with $30 \mathrm{mg}$ of FSH dissolved in either $10 \mathrm{ml}$ of PVP or 10 $\mathrm{ml}$ of saline, respectively. In Experiment 2, the efficacy of a single FSH injection was compared between 15 Japanese Black cows and 12 heifers. In experiment 1, a larger number of ova and embryos was observed with FSH dissolved in PVP than in saline (9.8 \pm 2.4 versus 0$)$. In experiment 2, the average number of embryos and transferable embryos in the control group (12.0 \pm 8.4 and 6.0 \pm 4.7$)$ and experimental cows $(10.4 \pm 7.6$ and $5.2 \pm 2.2)$ were significantly higher $(\mathrm{P}<0.01)$ than in heifers $(2.8 \pm 3.1$ and $1.1 \pm 1.9)$.
\end{abstract}

Key words: Superovulation, Single injection, FSH, Cows, Heifers.

(J. Reprod. Dev. 39: 353-356, 1993)

$\mathbf{T}$ he variability in quantity and quality of ova/ embryos following superovulation remains a major limiting factor in the development of practical embryo transfer programs in cattle [1-3]. To produce superovulation in cattle, either PMSG or FSH of pituitary origin is widely used. Pituitary FSH preparations produce the best superovulatory response in cattle, but they require 2 daily injections which is a technical inconvenience and can lead to errors in dose and injection time. It could also constitute a source of stress for some of the treated animals.

Recently Godke et al. [4] and Wubishet et al. [5] reported that continuous infusion of $\mathrm{FSH}$ can bring about superovulation, but only a few papers reported the efficacy by a single administration of

Accepted for Publication: July, 16, 1993

Correspondence: M. Yamamoto
FSH in cattle [6-8]. This study was undertaken to investigate the efficacy of a single i.m. injection with FSH dissolved in either polyvinylpyrroridone or saline and to compare the superovulatory response of cows and heifers.

\section{Materials and Methods}

Forty-two Japanese Black parous cows (average age $4.6 \mathrm{yr}$, weight $530 \mathrm{~kg}$ ) and 12 sexually mature heifers (average age 14 months, weight $360 \mathrm{~kg}$ ) were assigned to superovulatory treatments as follows:

Experiment 1: Sixteen cows were randomly assigned to 2 treatment groups. Each of the eight cows in the PVP group were given a single i.m. injection with $30 \mathrm{mg}$ of refined FSH (FSH-R; 
containing 0.6\% LH, Denka Pharmaceutical Inc. Kawasaki, Japan) dissolved in $10 \mathrm{ml}$ of $30 \%$ polyvinylpyrroridone solution (PVP; 40.000 molecular weight, Denka Pharmaceutical Inc, Japan). Eight cows in the saline group were given a single i.m. injection of $30 \mathrm{mg}$ of FSH dissolved in $10 \mathrm{ml}$ of saline.

Experiment 2: In Group 1, eleven control cows were given a total dose of $30 \mathrm{mg} \mathrm{FSH}-\mathrm{R}$ twice daily in declining doses $(6,6 ; 4,4 ; 3,3$ and $2,2 \mathrm{mg})$ for 4 days. Fifteen cows in group 2 and 12 heifers in group 3 were given a single i.m. injection with FSH-R (30 mg) dissolved in $10 \mathrm{ml}$ of PVP. Each animal also received prostaglandin $F_{2 \alpha}(30 \mathrm{mg}$, Lutalyse, Upjon Co., Kalamazoo, MI) 48 h after initiation of treatment.

The treated animals were inseminated with frozen semen at 12 and $24 \mathrm{~h}$ after onset of estrus. Ova and embryos were collected on day 7 postinsemination (day $0=$ estrus) employing a modification of previously described techniques [9-11]. Each ovary was examined by ultrasound sector scanner (type 500, Aloka, Tokyo, Japan) to determine the number of corpora lutea (CL) and unovulated follicles greater than $10 \mathrm{~mm}$ in diameter on the day of ova and embryo collection. The data were analyzed by Student's $t$-test.

\section{Results}

In experiment 1 (Table 1), the number of

Table 1. Influence of $30 \%$ PVP solution as a solvent for FSH as a single i.m. injection on superovulation in cows (Exp. 1). Number of CL and follicles examined on day 7 when ova/ embryos were recovered

\begin{tabular}{lcc}
\hline Group & FSH in Saline & FSH in PVP \\
No. of treated & 8 & 8 \\
No. of CL & $0.7 \pm 1.3^{\mathrm{a}}$ & $12.9 \pm 1.5^{\mathrm{b}}$ \\
$\begin{array}{l}\text { No. of follicles } \\
\text { *Rate of recovered } \\
\text { ova/embryo (\%) }\end{array}$ & $4.2 \pm 2.8$ & $1.8 \pm 1.6$ \\
$\begin{array}{l}\text { No. of recovered } \\
\text { ova/embryos }\end{array}$ & $0^{\mathrm{a}}$ & $76.6 \pm 3.7^{\mathrm{b}}$ \\
$\begin{array}{l}\text { No. of transferable } \\
\text { embryos }\end{array}$ & $0^{\mathrm{a}}$ & $9.8 \pm 2.4^{\mathrm{b}}$ \\
\hline
\end{tabular}

ab; $\mathrm{P}<0.01$

*; No. of recovered ova and embryo/No. of CL
Table 2. Superovulation responses of Japanese Black Cows and Heifers treated with 2 kinds of FSH administrations. Number of $\mathrm{CL}$ and follicles examined on day 7 when ova/embryos were recovered

\begin{tabular}{|c|c|c|c|}
\hline Treatment group & Control (1) & $\operatorname{Cow}(2)$ & Heifer(3) \\
\hline $\begin{array}{l}\text { No. of donors } \\
\text { treated }\end{array}$ & 11 & 15 & 12 \\
\hline No. of CL & $13.8 \pm 2.5^{\mathrm{a}}$ & $12.0 \pm 3.9^{\mathrm{a}}$ & $3.8 \pm 3.7^{\mathrm{b}}$ \\
\hline $\begin{array}{l}\text { No. of unovu- } \\
\text { lated follicles }\end{array}$ & $1.8 \pm 2.0^{c}$ & $2.1 \pm 1.6^{\mathrm{c}}$ & $5.2 \pm 4.9^{\mathrm{d}}$ \\
\hline $\begin{array}{l}* \text { Recovery rate } \\
(\%)\end{array}$ & $87.0 \pm 0.8$ & $86.7 \pm 4.1$ & $73.7 \pm 7.5$ \\
\hline $\begin{array}{l}\text { Average no. of } \\
\text { ova/embryos } \\
\text { recovered } \\
(\text { Mean } \pm \text { SD) }\end{array}$ & $12.0 \pm 8.4^{\mathrm{a}}$ & $10.4 \pm 7.6^{\mathrm{a}}$ & $2.8 \pm 3.1^{\mathrm{b}}$ \\
\hline $\begin{array}{l}\text { Average no. of } \\
\text { transferable } \\
\text { embryos } \\
(\text { Mean } \pm S D)\end{array}$ & $6.0 \pm 4.7^{\mathrm{c}}$ & $5.2 \pm 2.2^{\mathrm{c}}$ & $1.1 \pm 1.9^{\mathrm{d}}$ \\
\hline \multicolumn{4}{|c|}{$\begin{array}{l}\text { ab; } \mathrm{P}<0.01^{\mathrm{cd}} ; \mathrm{P}<0.05 \\
\text { Control (group 1): Cows were given a total of } 30 \mathrm{mg}(6,6 ; \\
4,4 ; 3,3 \text { and } 2,2 \mathrm{mg} \text { ) FSH-R dissolved in saline twice daily in } \\
\text { declining doses for } 4 \text { days. } \\
\text { Cow, Heifer (group } 2,3 \text { ): Cows and heifers were given a } \\
\text { single i.m. injection of } 30 \mathrm{mg} \text { of } \mathrm{FSH}-\mathrm{R} \text { dissolved in } 30 \% \\
\text { PVP solution. } \\
\quad \text {; No. of recovered ova and embryos/No. of CL }\end{array}$} \\
\hline
\end{tabular}

corpora lutea in the PVP group $(12.9 \pm 1.5)$ was significantly higher $(\mathrm{P}<0.01)$ than the saline group $(0.7 \pm 1.3)$. Unovulated follicles were more common in the saline group $(4.2 \pm 2.8)$ than in the PVP group (1.8 \pm 1.6$)$. In the PVP group, the number of ova/embryos and transferable embryos were $9.8 \pm 2.4$ and $7.0 \pm 2.2$, respectively, but in the saline group, no embryos were recovered.

In experiment 2 (Table 2), the number of corpora lutea in controls (13.8 \pm 2.5$)$ and experimental cows $(12.0 \pm 3.9)$ was significantly higher $(\mathbf{P}<0.01)$ than that of heifers $(3.8 \pm 3.7)$. Unovulated follicles were increased in heifers $(5.2 \pm 4.9)$ compared with those in controls and cows, while the number of recovered ova and embryos was significantly higher $(\mathrm{P}<0.05)$ in controls and cows than in heifers. The number of transferable embryos in controls and cows was also significantly higher than that in heifers $(\mathrm{P}<0.05)$. 


\section{Discussion}

The present data demonstrate that a single injection of FSH in PVP produced increased numbers of CL and all classes of ova and embryos (Table 1). In experiment 1, a greater beneficial effect was observed when FSH was dissolved in PVP compared to saline. These results indicate that a single injection of FSH in PVP produces multiple ovulations, and this method may be useful for induction of multiple ovulations in cows. To our knowledge, these profiles have never been described previously. In this study, it was not possible to calculate the half-life of FSH mathematically, but present results indicate that PVP is a suitable solvent to prolong the absorption of FSH given in a single injection.

A single injection of FSH in saline stimulated multiple follicular growth but did not lead to ovulation in several cows. This indicates that a single injection of FSH dissolved in saline does not induce ovulation and/or nucleic maturation of the oocytes. The half life of FSH in cows after treatment as calculated from the decay curve was found to be $301 \pm 23 \mathrm{~min} \mathrm{[12].} \mathrm{Therefore,} \mathrm{it} \mathrm{is}$ necessary to use multiple injections to induce superovulation in cows treated with FSH dissolved in saline.

In experiment 2 , the combined average number of total ova and transferable embryos in controls and experimental cows given a single i.m. injection of FSH dissolved in PVP was significantly higher $(\mathrm{P}<0.01)$ than that of heifers. A considerable number of unovulated follicles was present in the ovaries on day 7 , and, despite the large ovarian response, the percentage of transferable embryos recovered was comparatively low in heifers. These results indicate that there is an optimum dose level of FSH, and that administration of higher doses decreases fertilization and transferable embryo rates in heifers. This concept is further supported by the observation of McGowan et al. [13] that high levels of follicular stimulation usually produced poor quality embryos and increased the number of unfertilized ova. By extrapolation, a dose level below $20 \mathrm{mg}$ of FSH may be more satisfactory in heifers.

The results of this study clearly show that a single injection of FSH dissolved in PVP produces multiple ovulations and the recovery of larger numbers of transferable embryos in cattle. It may therefore provide a useful alternative to multiple administrations of FSH or PMSG.

\section{Acknowledgments}

The authors thanks Dr. M. Kawaguchi for assistance with statistical analysis. This work was supported by Denka Pharmaceutical Inc., Kawasaki, Japan.

\section{References}

1. Betterridge $\mathbf{K J}$. Techniques and results in cattle. In: Betterridge KJ (eds.), Embryo Transfer in Farm Animals. Dept. Agriculture, Ottawa, Canada,: Monograph 16; 1977: 1-9.

2. Chupin D, Saumande J. New attempts to decrease the variability of ovarian response to PMSG in cattle. Ann Biol Anim Bioch Biophys 1979; 19: 1489-1498.

3. Elsden RP, Nelson LD, Seidel Jr GE. Superovulation of cows with follicle stimulating hormone and pregnant mare's serum gonadotropin. Theriogenology 1978; 9: 17-23.

4. Godke RA, Bercovitz AB, Lambeth VA. Continuous infusion methods for superovulating beef and dairy cattle. The Louisiana Cattleman 1980; 13: 4 and 6.

5. Wubishet A, Graves CN, Spahr DJ. Continuous subcutaneous infusion of follicle-stimulating hormone as a method of superovulating dairy cows. Theriogenology 1986; 25: 809-811.

6. Mills AC, Warnic AC, Bazer FW, Burns WC, Peacock FM. Response to a single FSH injection in beef cattle fed MGA. J Anim Sci 1971; 32: 387.

7. Smith Jr LE, Sitton GD, Vincent CK. Limited injections of follicle-stimulating hormone for multiple birth in beef cattle. J Anim Sci 1973; 37: 523-527.

8. Vincent CK, Ladd HW, Pittman SL, Smith Jr LE. Superovulation of cattle with FSH in gelatin capsules. Louisiana Livestock Prod Rep 1973; 13: 120-123.

9. Suzuki T, Suzuki M, Shimohira I, Hujiyama M. An automatic flushing instrument for bovine embryo. Jpn J Anim Reprod 1984; 30: 194-196. 
10. Hasler JF, Mccanley AD, Schermerhorn EC, Foote RH. Superovulatory responses of Holstein cows. Theriogenology 1983; 19: 83-99.

11. Donaldoson LE. The effect of prostaglandin $\mathrm{F}_{2 \alpha}$ treatment in superovulated cattle on estrus response and embryo production. Theriogenology 1983; 20: 279-285.

12. Demoustier MM, Beckers J-Fr, Van Der Zwalmen
P, Closset J, Gillard J-L, Ectors Pr. Determination of porcine plasma follitropin levels during superovulation treatment in cows. Theriogenology 1988; 30: 379-386.

13. McGowan MR, Braithwaite M, Jochle W. Superovulation of beef heifers with Pergonal (HMG): A dose response trial. Theriogenology 1985; 24: 173184. 